Vol. 01, No. 1, Mei, 2021

http://journal.um-surabaya.ac.id/index.php/sustainable/index

\title{
KONTRIBUSI PAJAK DAN BEA BALIK NAMA KENDARAAN BERMOTOR DI PROVINSI JAWA TIMUR (Studi Kasus Pada Masa Pandemi Covid-19)
}

\author{
Dina Nur Safitri \\ Universitas Muhammadiyah Surabaya \\ dinanursafitri1@gmail.com
}

\begin{abstract}
This study aims to determine how is the contribution of PKB (Taxes) and BBNKB (Transfer Fees for Motorized Vehicles) in East Java Province to the Regional Revenue. The study is conducted at the Regional Revenue Agency of East Java Province with a qualitative descriptive method. The data are collected in the form of secondary data, field surveys in the form of documentation. The results of the study show that PKB and BBNKB revenues in $2018-2020$ in East Java Province is that the average contribution of motor vehicle taxes (PKB) to the regional revenue is $40.10 \%$ called as in a good category and the average contribution of motor vehicle title transfer fees (BBNKB) to the regional revenue is $20,10 \%$ called as in the medium category. However, the revenue of motor vehicle tax and motor vehicle transfer fees always exceeds the target. The Regional Government policy on the increasing of PKB and $B B N K B$ revenues during the Covid-19 pandemic is to waive fines for late payment of $P K B$ as well as exempt administrative sanctions of $P K B$ and $B B N K B$ and provide basic payment cuts of $P K B$ for two-wheelers and fourwheelers. In order to increase the contribution level of $P K B$ and $B B N K B$ to the regional revenue of East Java Province, cooperation between the government and taxpayers is needed.

Keywords: Contribution, Regional Revenue, PKB, BBNKB, the Covid-19 Pandemic
\end{abstract}

\begin{abstract}
ABSTRAK
Penelitian ini bertujuan untuk mengetahui seberapa besar kontribusi PKB dan BBNKB di Provinsi Jawa Timur terhadap Pendapatan Asli Daerah. Penelitian dilakukan di Badan Pendapatan Daerah Provinsi Jawa Timur dengan metode yang bersifat deskripsi kualitatif, yaitu dengan mengumpulkan data yang berupa data sekunder, survey lapangan berupa dokumentasi. Hasil Penelitian menunjukkan bahwa penerimaan PKB dan BBNKB tahun 2018 - 2020 di Provinsi Jawa Timur yaitu rata-rata kontribusi Pajak Kendaraan Bermotor terhadap PAD adalah sebesar 40,10 persen dalam kategori baik dan rata-rata kontribusi Bea Balik Nama Kendaraan Bermotor terhadap PAD adalah sebesar 20,10 persen dalam kategori sedang. Namun, penerimaan Pajak Kendaraan Bermotor dan Bea Balik Nama Kendaraan Bermotor selalu melebihi target yang sudah ditetapkan. Kebijakan Pemerintah Daerah terhadap peningkatan penerimaan PKB dan BBNKB pada masa pandemi Covid-19 yaitu dengan membebaskan denda keterlambatan PKB serta membebaskan sanksi administratif PKB dan BBNKB dan memberikan potongan pokok PKB untuk roda dua dan roda empat. Supaya tingkat kontribusi dari PKB dan BBNKB terhadap PAD Provinsi Jawa Timur terus meningkat maka dibutuhkannya kerjasama antara pemerintah dan wajib pajak.
\end{abstract}

Kata Kunci: Kontribusi, PAD, PKB, BBNKB, Covid-19.

Submitted: Maret 2021

Revised: April 2021

Accepted: Mei 2021

Correspondence to : dinanursafitri1@gmail.com 


\section{Jurnal Sustainable}

Vol. 01, No. 1, Mei, 2021

http://journal.um-surabaya.ac.id/index.php/sustainable/index

\section{PENDAHULUAN}

Negara Indonesia menjadi salah satu dari beberapa negara dengan kasus terbanyak yang mengalami masa pandemi Covid-19. Telah tercatat sebesar 56.385 jiwa yang memiliki kasus positif covid-19 dengan kasus jumlah angka kematian tercatat kurang lebih sebesar 2.876 jiwa akhir Juni 2020 di Indonesia. Rata-rata penambahan kasus baru per hari meningkat sebesar 977 kasus, sementara rata-rata orang yang dites per hari tercatat sebanyak 8.456 jiwa (Novianti dkk, 2020:24). Adanya pandemi ini membuat perekonomian menurun sehingga mendapatkan konsekuensi yang harus dihadapi dalam mengatasi dampak yang ditimbulkan.

Peraturan Menteri Keuangan dalam menyelesaikan permasalah perekonomian dampak dari Covid-19 dengan mengesahkan insentif pajak No. 110/PMK.08/2020 menggantikan PMK No.23/PMK.03/2020 yang telah diterbitkan pada awal bulan April tahun 2020, cara ini dapat intensif pajak dalam menjaga ke stabilan perekonomian nasional yang sedang menurun akibat Covid-19, berikut ini merupakan intensif pajak yang diberikan dan diperpanjang jangka waktu masa pajak Desember tahun 2020 dengan pemberian insentif, kenaikan besarnya pengurangan angsuran PPh menjadi 50\% (IAI, 2021: 23).

Pemerintahan daerah dalam menyelenggarakan pemerintahannya serta memberikan kesempatan dan keleluasaan kepada setiap daerah untuk menyelenggarakan otonomi daerahnya sendiri yang terdapat pada Undang- Undang Nomor 32 Tahun 2004.

Tabel 1. Data Target dan Realisasi PAD Jawa Timur Tahun 2020.

\begin{tabular}{lll}
\hline NO & \multicolumn{1}{c}{ JENIS PUNGUTAN } & \multicolumn{1}{c}{$\begin{array}{c}\text { REALISASI } \\
2020(\mathrm{Rp})\end{array}$} \\
\hline 1 & PKB & $6.566 .187 .985 .216,00$ \\
\hline 2 & BBNKB & $3.022 .188 .308 .400,00$ \\
\hline 3 & PBBKB & $2.086 .916 .789 .124,00$ \\
\hline 4 & PAP & $33.958 .816 .230,00$ \\
\hline 5 & Pajak Rokok & $2.703 .415 .327 .323,00$ \\
\hline Jumlah Pajak Daerah & $14.412 .667 .226 .293,00$ \\
\hline 6 & Retribusi Daerah (Dikelola Bapenda Jatim) & $21.667 .287 .585,00$ \\
\hline 7 & Pendapatan Lain-lain & $25.427 .440 .815,00$ \\
\hline Jumlah & $14.438 .094 .667 .108,00$ \\
\hline
\end{tabular}

Sumber: Badan Pendapatan Daerah Provinsi Jawa Timur,2021

Berdasarkan beberapa jenis pajak daerah yaitu Pajak kendaraan bermotor dan bea balik nama kendaraan bermotor dapat berkontribusi yang baik terhadap Pendapatan Asli Daerah Provinsi Jawa Timur. Penerimaan pajak kendaraan bermotor dan bea balik nama kendaraan 


\section{Jurnal Sustainable}

Vol. 01, No. 1, Mei, 2021

http://journal.um-surabaya.ac.id/index.php/sustainable/index

bermotor sangat berkaitan dengan pembayaran yang dilakukan wajib pajak, kebutuhan kendaraan bermotor sangat memiliki kepentingan yang digunakan sebagai alat transportasi dan sebagai sarana untuk mencari nafkah. Pajak kendaraan bermotor dikenakan karena suatu kepemilikan atau penguasaan kendaraan bermotor, sedangkan pajak bea balik nama kendaraan bermotor dikenakan karena penyerahan hak milik kendaraan bermotor sehingga terjadinya perjanjian dua pihak atau lebih dan keadaan terjadi karena jual beli, tukar menukar, hibah, warisan atau dari pemasukan ke dalam badan usaha. Pendapatan Asli Daerah di Provinsi Jawa Timur dapat menjadikan provinsi yang mandiri dengan mendapatkan kontribusi yang baik dari pajak kendaraan bermotor dan bea balik nama kendaraan bermotor sehingga dapat menata keuangannya dengan baik tanpa harus menunggu bantuan dan kiriman dari pemerintah pusat. Telah diatur dalam Undang - undang Pasal 1 No. 28 Tahun 2009 tentang Pajak Daerah dan Restribusi Daerah, merupakan kontribusi wajib pajak daerah kepada badan yang bersifat pribadi dan tidak ada imbalan secara langsung yang digunakan bagi daerah.

Pajak berdasarkan lembaga pemungutannya dibagi menjadi dua bagian yaitu Pajak Pusat dan Pajak Daerah. Pajak Pusat merupakan pajak yang dipungut oleh pemerintah pusat yang diserahkan ke Direktorat Jenderal Pajak Keuangan guna membiayai rumah tangga negara, Administrasi, Pembinaan, dan Pengawasannya dan pajak pusat terdiri atas pajak : penghasilan, pertambahan nilai , penjualan atas barang mewah, bea materai, dan PBB-P3 (Halim dkk, 2020: 499). Sedangkan pajak daerah guna membiayai rumah tangga daerah sehingga pajak daerah merupakan pajak yang dipungut oleh pemerintahan daerah.

Denda PKB dan BBNKB yang diberikan pada masa pandemi sangat berbeda dengan tahun sebelumnya. Kebijakan yang diberikan oleh pemerintah adanya pandemi ini yaitu dengan memberikan kebebasan atas denda keterlambatan bagi Pajak Kendaraan Bermotor (PKB) dan juga Bea Balik Nama Kendaraan Bermotor (BBNKB), serta insentif potongan pokok pajak PKB untuk roda dua sebesar 15\% dan roda empat atau lebih sebesar 5\% bagi wajib pajak yang terdampak pandemi covid-19 yang tertuang dalam keputusan Gubernur Jatim Nomor 188/334/KPTS/013/2020 tentang Pemberian Insentif Pajak Daerah bagi Masyarakat Jatim dengan didukung refrensi dari pemerintah pusat yang juga memberikan perpanjangan insentif pajak sampai Desember tahun 2020 yang tercantum dalam Peraturan Menteri Keuangan Nomor 86 Tahun 2020 tentang Insentif Pajak bagi Wajib Pajak terdampak pandemi covid-19 (sumber: 


\section{Jurnal Sustainable}

Vol. 01, No. 1, Mei, 2021

http://journal.um-surabaya.ac.id/index.php/sustainable/index

dipendajatim.go.id). Kebijakan pemerintah diupayakan dapat meringankan beban masyarakat sehingga dapat berkontribusi dalam mendukung pemulihan Pendapatan Asli Daerah terutama di Provinsi Jawa Timur pada masa pandemi Covid-19.

\section{TINJAUAN TEORITIS DAN HIPOTESIS}

\section{Pajak}

Pajak dari beberapa para ahli memang dalam mendefinisikannya itu berbeda-beda, akan tetapi intinya tetap sama seperti diungkapkan oleh S.I. Djajadiningrat bahwa pajak merupakan kewajiban dengan menyerahkan sebagian dari kekayaan ke kas negara atas dasar suatu keadaan, perbuatan yang memberikan kedudukan tertentu, dan kejadian, tetapi bukan sebagai hukuman, menurut peraturan yang ditetapkan pemerintah dapat dipaksakan, tetapi tidak ada timbal balik dari negara secara langsung dapat memelihara kesejahteraan secara umum (Resmi, 2019: 1).

Ada dua fungsi pajak: (1) Fungsi Budgetair atau sumber keuangan negara digunakan pemerintah untuk membiayai pengeluaran dalam pembangunan. (2) Fungsi Regulared atau Pengatur yang dimana pajak sebagai alat mengatur atau melaksanakan kebijakan pemerintah dalam bidang sosial dan ekonomi.

Menurut Suandy (2016: 37) Pajak Daerah merupakan pemungutan pajaknya yang mempunyai kewenangannya kepada pemerintah daerah dan dilaksanakan oleh Dinas Pendapatan Daerah. Pajak Daerah terbagi menjadi dua bagian, yaitu Pajak Provinsi dan Pajak Kabupaten/Kota yaitu sebagai berikut:

a. Pajak Daerah Provinsi, terdiri dari:

1. Pajak Kendaraan Bermotor.

2. Pajak Balik Nama Kendaraan Bermotor.

3. Pajak Bahan Bakar Kendaraan Bermotor.

4. Pajak Air Permukaan.

5. Pajak Rokok.

b. Pajak Daerah Kabupten/Kota, terdiri dari:

1. Pajak Hotel.

2. Pajak Restoran. 


\section{Jurnal Sustainable}

Vol. 01, No. 1, Mei, 2021

http://journal.um-surabaya.ac.id/index.php/sustainable/index

3. Pajak Hiburan.

4. Pajak Reklame.

5. Pajak Penerangan Jalan.

6. Pajak Mineral Bukan Logam dan Batuan.

7. Pajak Parkir.

8. Pajak Air Tanah.

9. Pajak Sarang Burung Walet.

10. Pajak Bumi dan Bangunan Pedesaan dan Perkotaan.

11. Bea Perolehan Hak atas Tanah dan Bangunan.

Menurut Suandy (2016: 39) dalam pemungutan pajak adatiga macam cara yang biasa dilakukan yaitu sebagai berikut:

1. Asas Domisili (Tempat Tinggal)

Pemungutan pajaknya berdasarkan domisili atau tempat tinggal yang berhak memungut kepada wajib pajak tanpa melihat dari mana penghasilan atau pendapatan yang diperoleh, baik dari dalam atau luar negeri dan tanpa melihat kebangsaanwajib pajak tersebut.

2. Asas Sumber

Negara pemungutan pajak berhak bersumber dari pendapatan atas penghasilan tanpa memerhatikan domisili dan kewarganegaraan wajib pajak.

3. Asas Kebangsaan

Pengenaan pajaknya didasarkan pada kebangsaan atau kewarganegaraan dari wajib pajak yang bersangkutan, tanpa melihat dari mana sumber pendapatan atau penghasilan.

Sistem pemungutan pajak merupakan suatu metode dengan mengukur besarnya pajak yang wajib dibayar ke Negara. Menurut Halim, dkk (2020: 7) sistem pemungutan pajak dibagi dalam tiga bagian sebagai berikut :

1. Official Assesment System

Sistem pemungutan pajaknya meberikan kewenangan kepada pemerintah untuk menentukan besarnya pajak terutang oleh wajib pajak menurut perundang-undang perpajakan yang berlaku. 


\section{Jurnal Sustainable}

Vol. 01, No. 1, Mei, 2021

http://journal.um-surabaya.ac.id/index.php/sustainable/index

\section{Self Assessment System}

Sistem pemungutan pajak yang memberikan kewenangan dalam menentukan sendiri jumlah wajib pajak dalam memperhitungkan, membayar dan melaporkan sendiri besarnya pajak yang harus dibayar yang terutang setiap tahunnya sesuai dengan peraturan perundang-undangan perpajakan yangberlaku.

3. With Holding System

Sistem pemungutan pajaknya memberikan kewenangan kepada pihak ketiga bukan dari wajib pajak digunakan untuk menentukan besarnya pajak yang terutang oleh wajib pajak.

Teori yang mendukung dalam pemungutan pajak pada dasarnya pemerintah harus melakukannya. Berikut ini teori yang mendukung pemungutan pajak menurut Resmi (2019: 5) sebagai berikut:

1. Teori Asuransi

Dalam melindungi masyarakat tugas yang diupayakan Negara dengan mengutamakan keselamatan dan keamanan masyarakat bersama harta bendanya.

2. Teori Kepentingan

Perlindungan masyarakat berasal dari pembagian wajib pajak kepada Negara.

3. Teori Daya Pikul

Wajib pajak bagi masyarakat harus dibayarkan sesuai dengan daya pikul setiap orang dan harus dibagi sama rata.

4. Teori Bakti

Kewajiban membayar pajak kepada Negara secara mutlak untuk warga Negara.

5. Teori Asas Daya Beli

Pendapat dari teori ini bahwa pemungutan pajak mempunyaifungsi dalam mengambil daya beli dari rumah tangga masyarakat untuk rumah tangga negara, sehingga dapat menyalurkan kembali ke masyarakat bertujuan untuk mendukung kehidupan masyarakat dalam kesejahteraan.

\section{Pendapatan Asli Daerah}

Pendapatan asli daerah merupakan indikator dari anggaran pendapatan belanja daerah. Dalam pelaksanaan pembangunan daerahnya pemerintah daerah harus mempunyai 
Vol. 01, No. 1, Mei, 2021

http://journal.um-surabaya.ac.id/index.php/sustainable/index

sumber keuangan. Berdasarkan Pasal 1 Undang-undang Nomor 33 Tahun 2004 Pendapatan Asli Daerah merupakan sumber penerimaan yang diperoleh dari daerahnya yang dipungut berdasarkan peraturan peraturan perundang-undang yang berlaku.Pendapatan Asli Daerah menjadi sumber penting dalam pendapatan daerahnya sendiri dengan bertujuan agar dapat terlaksananya hasil pembangunan yang dibuat oleh Pemerintah bagi masyarakat.

Adapun sumber Pendapatan Asli Daerah yaitu terdiri atas: (1) Pajak Daerah, (2) Retribusi Daerah, (3) Hasil Pengelolaan Kekayaan Milik Daerah yang Dipisahkan, (4) Lainlain PAD yang Sah.

\section{Pajak Kendaraan Bermotor}

Menurut Halim, dkk (2020: 503) Undang-undang Nomor 28 Tahun 2009 menyatakan bahwa Pajak Kendaraan Bermotor merupakan pajak atas kepemilikan penguasaan kendaraan bermotor. Kendaraan Bermotor ini merupakan kendaraan yang beroda dua atau lebih yang digerakkan oleh peralatan teknik berupa motor, mobil atau peralatan lainnya yang dapat digunakan disemua jenis jalan darat (Aswati dkk, 2018: 29).

Dasar pengenaan pajak kendaraan bermotor berasal dari dua unsur dari nilai jual kendaraan bermotor yang sudah ditentukan dengan harga pasar kendaraan bermotor atau bobot dengan mencerminkan kadar kerusakan jalan yang diakibatkan penggunaan kendaraan bermotor.

\section{Bea Balik Nama Kendaraan Bermotor}

Berdasarkan Peratudan Daerah No 9 Tahun 2010 Bea Balik Nama Kendaraan Bermotor merupakan wajib pajak dalam pemberian hak milik kendaraan atas perjanjian dua pihak atau lebih karena terjadi adanya jual beli, tukar menukar, hibah, warisan dan lain-lain.

Menurut Halim, dkk (2020: 506) menyatakan bahwa objek pajak Bea Balik Nama Kendaraan Bermotor merupakan penyerahan atas kendaraan bermotor dalam hak kepemilikan. Subjek dan wajib pajak Bea Balik Nama Kendaraan Bermotor merupakan orang pribadi atau badan usaha, yang memperoleh pemberian kendaraan. Lamanya jangka waktu dalam penyerahan kendaraan bermotor dari orang pertama ke penyerahan berikutnya merupakan masa pajak Bea Balik Nama Kendaraan Bermotor.

\section{Kontribusi}




\section{Jurnal Sustainable}

Vol. 01, No. 1, Mei, 2021

http://journal.um-surabaya.ac.id/index.php/sustainable/index

Menurut Soekanto dalam penelitian Fitri (2020 : 7) menjelaskan bahwa kontribusi sebagai bentuk iuran uang dan/atau dana, bantuan tenaga,pemikiran, materi, dan segala macam bentuk bantuan dan/atau sumbangan yang kiranya dapat membantu berjalanannya sutau kegiatan pada satu lingkungan, perkumpulan dan lain-lain.

Menurut Boedjoewono dalam penelitian Rizal dan Hidayah (2018: 88) untuk mengetahui seberapa besar kontribusi Pajak Kendaraan Bermotor dan Bea Balik Nama Kendaraan Bermotor terhadapPendapatan Asli Daerah dapat menggunakan formulasi sebagai berikut:

Berikut perhitungan kontribusi PKB dan BBNKB terhadap Pendapatan Asli Daerah :

\section{Realisasi PKB dan BBNKB per Tahun}

Kontribusi $=$ $\times 100 \%$

\section{Realisasi PAD per Tahun}

Sebagaimana PKB (Pajak Kendaraan Bermotor); BBNKB (Bea Balik Nama Kendaraan Bermotor); dan PAD (Pendapatan Asli Daerah). Dengan melakukan perhitungan Kontribusi Pajak Kendaraan Bermotordan Bea Balik Nama Kendaraan Bermotor di atas untuk mengetahui presentasenya yaitu dari realisasi PKB dibandingkan dengan total realisasi PAD dan realisasi BBNKB dibandingkan dengan total realisasiPAD.

Tabel 2. Klasifikasi Kriteria Kontribusi

\begin{tabular}{ll}
\hline Persentase & Kriteria \\
\hline $0,00 \%-10 \%$ & Sangat Kurang \\
\hline $10,10 \%-20 \%$ & Kurang \\
\hline $20,10 \%-30 \%$ & Sedang \\
\hline $30,10 \%-40 \%$ & Cukup Baik \\
\hline $40,10 \%-50 \%$ & Baik \\
\hline$>50 \%$ & Sangat Baik \\
\hline
\end{tabular}

Sumber: Tim Litbang Depdagri, Tahun 2013 dalam penelitian Rizal danHidayah (2018: 89) 


\section{Jurnal Sustainable}

Vol. 01, No. 1, Mei, 2021

http://journal.um-surabaya.ac.id/index.php/sustainable/index

\section{Efektivitas}

Menurut Aryani (2020: 26) efektifitas merupakan sebuah pencapaian atau kegagalan dari kegiatan untuk telaksanakannya suatu tujuan. Menurut Duri dalam penelitian Tanan dan Doko (2021: 381) menyatakan dalam mengitung efektivitas penerimaan dengan membandingkan realisasi dan target yang sudah dianggarkan. Sehingga untuk menghitung perbandingan atau efektivitas target dan realisasi, maka menggunakan rumus menurut Vita dalam penelitian Putri dan Saputra(2020: 136) sebagai berikut :

\section{Realisasi PKB dan BBNKB}

Efektivitas $=\longrightarrow \times 100 \%$

Target PKB dan BBNKB 


\section{Jurnal Sustainable}

Vol. 01, No. 1, Mei, 2021

http://journal.um-surabaya.ac.id/index.php/sustainable/index

\section{Kerangka Konseptual}

Gambar 1 Kerangka Konseptual

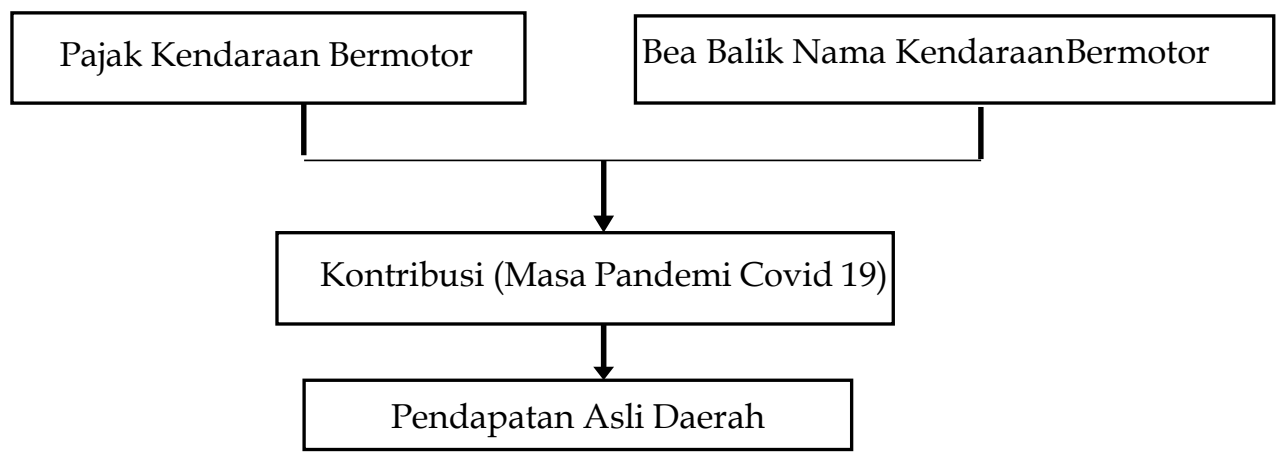

Berdasarkan gambar 1 kerangka pemikiran diatas, dapat dijelaskan bahwa untuk mengetahui kontribusi pajak kendaraan bermotor dan pajak bea balik nama kendaraan bermotor terhadap peningkatan pendapatan asli daerah dengan mengetahui banyaknya target dan realisasi yang sudah ditetapkan oleh daerahnya. Kemudian dimulai dari Pajak Kendaraan Bermotor dan Pajak Bea Balik Nama Kendaraan Bermotorke kontribusi (masa pandemi Covid-19). Dan dilakukannya perhitungan kontribusi Pajak Kendaraan Bermotor dan Bea Balik Nama Kendaraan Bermotor untuk mengetahui seberapa berkontribusi dalam peningkatan penerimaan Pendapatan Asli Daerah pada masa pandemi Covid-19 disuatu daerah. Peningkatan tersebut digunakan untuk mengetahui sejauh mana pajak kendaraan bermotor dan pajak bea balik nama kendaraan bermotor memberikan kontribusi dalam penerimaan Pendapatan Asli Daerah di Provinsi Jawa Timur.

\section{METODE PENELITIAN}

\section{Jenis Penelitian}

Penelitian yang digunakan oleh penulis adalah penelitian deskriptif kualitatif dengan pendekatan studi kasus. Jenis data yang digunakan dalam penelitian ini yaitu data sekunder yang diperoleh berdasarkan data Pajak Kendaraan Bermotor dan Bea Balik Nama Kendaraan Bermotor di Provinsi Jawa Timur. Untuk dapat menghitung kontribusi Pajak Kendaraan Bermotor dan Bea Balik Nama Kendaraan Bermotor dalam meningkatkan pendapatan asli 


\section{Jurnal Sustainable}

Vol. 01, No. 1, Mei, 2021

http://journal.um-surabaya.ac.id/index.php/sustainable/index

daerah Provinsi Jawa Timur. Dalam hal ini dapat melakukan perbandingan terhadap hasil yang telah dihitung peneliti dengan mengumpulan data serta menyusun dan menafsirkan data untuk memberikan gambaran atau penjelasan secara sistematis, faktual, dan akurat mengenai fakta yang ada.

\section{Pengumpulan Data}

Teknik pengumpulan data dalam penelitian ini sebagai berikut:

1. Wawancara

Wawancara yang dilakukan penelitian ini dengan mendapatkannya data atau informasi yang lebih runtun. Data penelitian didapatkan dari kegiatan wawancara antara opini.

2. Dokumentasi

Menurut Fatihudin (2019: 129) teknik Dokumentasi dilakukan dengan cara mengumpulan datayang bersumber dari laporan dan catatan yang ada kaitannya dengan masalah yang diteliti. Selain itu, dengan berbagai referensi yang berasal dari web resmi pemerintahan dengan atas nama lembaga Badan Pendapatan Daerah (BAPENDA) Provinsi Jawa Timur yangdigunakan peneliti dalam membantu untuk medapatkan data yang dibutuhkan.

\section{Tahapan Analisis}

Berikut merupakan tahapan teknik analisis data pada penelitian ini untuk mendapat data adalah sebagai berikut:

1. Mencari data mengenai target dan realisasi Pendapatan Asli Daerah, Pajak Kendaraan Bermotor dan Bea Balik Nama Kendaraan bermotor di Provinsi Jawa Timur sebelum dan pada masa pandemi covid-19 dengan penelitian secara online dengan mengunjungi website resmi milik Badan Pendapatan Daerah (BAPENDA) Provinsi Jawa Timur dan mencari data dengan terjun ke lapangan langsung untuk mencari sumber data dan menemui narasumber yang akan dituju peneliti.

2. Untuk mengurus surat ijin penelitian dalam mengambil data dari instansi pemerintah yang akan diajukan kepada Badan Kesatuan Bangsa dan Politik Provinsi Jawa Timur terlebih dahulu dengan menyerahkan surat dari fakultas.

3. Surat fakultas yang akan diberikan ke Badan Kesatuan Bangsa dan Politik Provinsi Jawa Timur dengan membawa berkas persyaratan mengenai proposal dan persetujuan dari 
Vol. 01, No. 1, Mei, 2021

http://journal.um-surabaya.ac.id/index.php/sustainable/index

dosen pembimbing supaya dapat dirujukan langsung ke instansi Badan Pendapatan Daerah ProvinsiJawa Timur.

4. Surat rujukan yang sudah didapatkan dari Badan Kesatuan Bangsa dan Politik akan diserahkan kepada instansi yang akan dilakukan sebagai tempat penelitian di Badan Pendapatan Daerah Provinsi Jawa Timur.

5. Berkas yang sudah sesuai dengan membawa Proposal, surat yangditerima dari Badan Kesatuan Bangsa dan Politik, surat ijin penelitian dari fakultas dan persetujuan dari dosen pembimbing ke Badan Pendapatan Daerah Provinsi Jawa Timur.

6. Kemudian mememperoleh dan/atau menerima surat persetujuan yang diberikan Badan Pendapatan Daerah Provinsi Jawa Timur untuk melakukan kegiatan penelitian.

7. Data yang diminta peneliti sudah terkumpul akan dilakukan analisis data kualitatif dengan metode deskriptif degan menjelaskan data yang sudah ada.

\section{HASIL PENELITIAN DAN PEMBAHASAN}

\section{Target dan Realisasi Pajak Kendaraan Bermotor dan Bea Balik Nama Kendaraan} Bermotor Provinsi Jawa Timur Tahun 2018 - 2020

Di Provinsi Jawa Timur merupakan provinsi yang besar termasuk dalam jumlah penduduknya ditiap tahunnya, maka hal ini berpengaruh dalam jumlah kendaraan bermotor dan obyek bea balik nama kendaraanbermotor di tahun 2018 - 2020.

Untuk mengetahui tingginya suatu penerimaan pajak kendaraanbermotor dan bea balik nama kendaraan bermotor di jawa timur, berikut disajikan data target dan realisasi penerimaan pajak kendaraan bermotordan bea balik nama kendaraan bermotor pada tahun $2018-2020$ :

a. Target dan Realisasi Pajak Kendaraan Bermotor

Tabel 3 Data Target dan Realisasi Pajak Kendaraan BermotorProvinsi Jawa Timur Tahun $2018-2020$

TARGET DAN REALISASI PAJAK KENDARAAN BERMOTOR

\begin{tabular}{lcc}
\hline Tahun & Target $(\mathrm{Rp})$ & Realisasi (Rp) \\
\hline 2018 & $5.400 .000 .000 .000,00$ & $6.488 .692 .325 .911,00$ \\
\hline
\end{tabular}




\section{Jurnal Sustainable}

Vol. 01, No. 1, Mei, 2021

http://journal.um-surabaya.ac.id/index.php/sustainable/index

\begin{tabular}{lll}
\hline 2019 & $6.350 .000 .000 .000,00$ & $6.890 .439 .193 .872,00$ \\
\hline 2020 & $5.600 .000 .000 .000,00$ & $6.566 .187 .985 .216,00$
\end{tabular}

Sumber: Badan Pendapatan Daerah Provinsi Jawa Timur,2021

Berdasarkan tabel 3. diatas, dapat dilihat bahwa penerimaan pajak kendaraan bermotor yang ditargetkan atau ditetapkan selama tahun 2018 hingga 2020 oleh Pemerintah Provinsi Jawa Timur telah mencapai target dan mengalami peningkatan pada tahun 2018 hingga 2019 dan adanya penurunan pada tahun 2020 pada masa pandemi Covid-19.

b. Target dan Realisai Bea Balik Nama Kendaraan Bermotor

Tabel 4. Data Target dan Realisasi Bea Balik Nama Kendaraan Bermotor Provinsi Jawa Timur 2018 - 2020

\begin{tabular}{lll}
\hline \multicolumn{3}{c}{ TARGET DAN REALISASI BEA BALIK NAMA KENDARAAN } \\
& \multicolumn{2}{c}{ BERMOTOR } \\
\hline Tahun & Target (Rp) & Realisasi (Rp) \\
\hline 2018 & $3.650 .000 .000 .000,00$ & $4.089 .296 .812 .767,00$ \\
\hline 2019 & $3.755 .000 .000 .000,00$ & $4.232 .540 .305 .900,00$ \\
\hline 2020 & $2.550 .000 .000 .000,00$ & $3.022 .188 .308 .400,00$ \\
\hline
\end{tabular}

Sumber: Badan Pendapatan Daerah Provinsi Jawa Timur,2021

Berdasarkan tabel 4. diatas, dapat dilihat bahwapenerimaan bea balik nama kendaraan bermotor yang ditargetkan atau ditetapkanselama tahun 2018 hingga 2020 oleh Pemerintah Provinsi Jawa Timur telah mencapai target dan mengalamipeningkatan pada tahun 2018 hingga 2019 dan adanya penurunan pada tahun hingga 2020 pada masa pandemi Covid-19.

\section{Penerimaan Pendapatan Asli Daerah Provinsi Jawa Timur}

Pendapatan Asli Daerah berasal dari pendapatan daerah itu sendiriyang bersumber dari hasil pajak daerah, hasil retribusi daerah, hasil pengelolaan kekayaan daerah yang dipisahkan, dan lain-lain pendapatan asli daerah yang sah, Adanya tujuan dengan mengambil pendanaan dalam terlaksanakannya otonomi daerah serta memberikan keleluasaan bagi daerahnya. Sehingga dalam penerimaan pajak inilah yang akan diutamakan karena peningkatan dari penerimaan pajak dapat berpengaruh baik terhadap penerimaan Pendapatan Asli Daerah. Untuk mengetahui peningkatan penerimaan Pajak 
Vol. 01, No. 1, Mei, 2021

http://journal.um-surabaya.ac.id/index.php/sustainable/index

Daerah Provinsi Jawa Timur, maka berikut ini dapat disajikan data target dan realisasi penerimaan pajak di Provinsi Jawa Timur tahun 2018 - 2020:

Tabel 5 Data Target dan Realisasi Pendapatan Asli DaerahProvinsi Jawa Timur 2018 - 2020

TARGET DAN REALISASI PENDAPATAN ASLI DAERAH

\begin{tabular}{lcc}
\hline \multicolumn{1}{c}{ Tahun } & Target (Rp) & Realisasi (Rp) \\
\hline 2018 & $13.520 .900 .000 .000,00$ & $15.088 .755 .704 .409,00$ \\
\hline 2019 & $14.916 .600 .000 .000,00$ & $15.547 .536 .261 .582,00$ \\
\hline 2020 & $12.398 .000 .000 .000,00$ & $14.438 .094 .667 .108,00$ \\
\hline
\end{tabular}

Sumber : Badan Pendapatan Daerah Provinsi Jawa Timur,2021

Berdasarkan tabel 5 diatas, dapat dilihat bahwa penerimaan Pendapatan Asli Daerah yang ditargetkan atau ditetapkan selama tahun2018hingga 2020 oleh Pemerintah Provinsi Jawa Timur telah mencapaitarget danmengalami peningkatan pada tahun 2018 hingga 2019 dan adanya penurunan pada tahun 2020 pada masa pandemi Covid-19.

\section{Target dan Realisasi Pajak Kendaraan Bermotor dan Bea Balik Nama Kendaraan Bermotor di Provinsi Jawa Timur pada Tahun 2018 - 2020}

a. Target dan realisasi Pajak Kendaraan Bermotor

Tabel 6 Persentase Realisasi Pajak Kendaraan Bermotor di ProvinsiJawa Timur 2018 $-2020$

\begin{tabular}{llll}
\hline \multicolumn{4}{l}{ TARGET DAN REALISASI PAJAK KENDARAAN BERMOTOR } \\
\hline Tahun & Target (Rp) & Realisasi (Rp) & PERSENTASE (\%) \\
\hline 2018 & $5.400 .000 .000 .000,00$ & $6.448 .692 .325 .911,00$ & $119,42 \%$ \\
\hline 2019 & $6.350 .000 .000 .000,00$ & $6.890 .439 .193 .872,00$ & $108,51 \%$ \\
\hline 2020 & $5.600 .000 .000 .000,00$ & $6.566 .187 .985 .216,00$ & $117,25 \%$
\end{tabular}

Sumber: Diolah peneliti,2021

Berdasarkan tabel diatas dapat diketahui bahwa tahun 2019 targetnya dibuat pada akhir tahun 2018, sedangkan diakhir 2018 masih belum mengalami masa pandemi Covid-19 di Indonesia. Dan hal ini dapat meningkatkan target yang tinggi pada tahun 


\section{Jurnal Sustainable}

Vol. 01, No. 1, Mei, 2021

http://journal.um-surabaya.ac.id/index.php/sustainable/index

2019, akan tetapi pada tahun 2020 target yang ditetapkan oleh pemerintah itu diturunkan karena pada tahun tersebut telah mengalami masa pandemi covid19.Pemenuhan penerimaan Pajak Kendaraan Bermotor, dapat bekerjasama antara pemerintah dan masyarakat sangatdiperlukan. Dimana pemerintah telah memberikan kebijakan yang memudahkan masyarakat sebagai wajib pajak untuk membayar pajaknya pada masa pandemi covid-19. Kemudahan dalam membantu program pemerintah yang diberikan ke Badan Pendapatan Daerah Provinsi Jawa untuk melakukan physical distancing. Adanya Kebijakan ini perlunya perhatian dalam meningkatkan kesadaran wajib pajak sehinggapenerimaan Kendaraan Bermotor di Jawa Timur bisa lebih baik dan wajib pajak dapat menyadari manfaat yang dapat diambil dari pemungutan pajak.

b. Target dan realisasi bea balik nama kendaraan bermotor

Tabel 7 Persentase Realisasi Bea Balik Nama Kendaraan Bermotor di Provinsi Jawa Timur 2018 - 2020

TARGET DAN REALISASI BEA BALIK NAMA KENDARAAN BERMOTOR

\begin{tabular}{cccc}
\hline Tahun & Target $(\mathrm{Rp})$ & Realisasi $(\mathrm{Rp})$ & Persentase $(\%)$ \\
\hline 2018 & $3.650 .000 .000 .000,00$ & $4.089 .296 .812 .767,00$ & $112,03 \%$ \\
\hline 2019 & $3.755 .000 .000 .000,00$ & $4.232 .540 .305 .900,00$ & $112,71 \%$ \\
\hline 2020 & $2.550 .000 .000 .000,00$ & $3.022 .188 .308 .400,00$ & $118,52 \%$ \\
\hline
\end{tabular}

Sumber: Diolah Peneliti,2021

Berdasarkan tabel diatas dapat diketahui bahwa persentasenya pada tahun 2020 mengalami kenaikan dibandingkan dengan tahun 2018 dan tahun 2019 setiap tahunnya mengalami kenaikan dalam targetnya dengan diiringi realisasi yang meningkat pula, akan tetapi pada tahun 2020 target yang ditetapkan makin diturunan seiring dengan realisasi yang dicapai juga menurun karena tahun tersebut mengalami masa pandemi Covid-19. Penerimaan Bea Balik Nama Kendaraan Bermotor, dikenakan berdasarkan penyerahan hak milik kendaraan bermotor berasal dari perjanjian dua pihak atau lebih dikenakan atas dasar jual beli, tukar menukar, hibah, warisan atau pemasukan kedalam badan usaha. Pembayaran Bea Balik Nama Kendaraan Bermotor dilakukan di SAMSAT 
Vol. 01, No. 1, Mei, 2021

http://journal.um-surabaya.ac.id/index.php/sustainable/index

induk dikarenakan adanya pengecekan fisik kendaraan bermotor dengan pengisian form, pergantian plat nomor dan penerimaanSTNK baru.

\section{Kontribusi Pajak Kendaraan Bermotor dan Bea Balik Nama Kendaraan Bermotor terhadap Pendapatan Asli Daerah di ProvinsiJawa Timur}

Tabel 8. Realisasi Pajak Kendaraan Bermotor dan Bea Balik NamaKendaraan Bermotor terhadap PAD Provinsi Jawa Timur tahun 2018 - 2020

$$
\text { Realisasi PKB(Rp) Realisasi BBNKB(Rp) Realisasi PAD(Rp) }
$$

Tahun

\begin{tabular}{llll}
\hline 2018 & 6.448 .692 .325 .911 & 4.089 .296 .812 .767 & 15.088 .755 .704 .409 \\
\hline 2019 & 6.890 .439 .193 .872 & 4.232 .540 .305 .900 & 15.547 .536 .261 .582 \\
\hline 2020 & 6.566 .187 .985 .216 & 3.022 .188 .308 .400 & 14.438 .094 .667 .108
\end{tabular}

Sumber: Badan Pendapatan Daerah Provinsi Jawa Timur, 2021

Berdasarkan rumus kontribusi penerimaan pajak kendaraan bermotor dan bea balik nama kendaraan bermotor maka cara menghitung tingkat kontribusi penerimaan Pajak Kendaraan Bermotor (PKB) dan Bea Balik Nama Kendaraan Bermotor (BBNKB) terhadap Pendapatan Asli Daerah (PAD) di Provinsi Jawa Timur adalah sebagai berikut:

a. Kontribusi realisasi PKB terhadap Pendapatan Asli Daerah

Tabel 9 Kontribusi Realisasi Pajak Kendaraan Bermotor terhadap PAD Provinsi Jawa Timur Tahun 2018 - 2020

\begin{tabular}{rlrrl}
\hline TAHUN & Realisasi PKB (Rp) & Realisasi PAD(Rp) & $\begin{array}{c}\text { Kontribusi } \\
(\%)\end{array}$ & Keterangan \\
\hline 2018 & 6.448 .692 .325 .911 & 15.088 .755 .704 .409 & $42,738 \%$ & Naik \\
\hline 2019 & 6.890 .439 .193 .872 & 15.553 .541 .429 .948 & $44,318 \%$ & Naik \\
\hline 2020 & 6.566 .187 .985 .216 & 14.438 .094 .667 .108 & $45,478 \%$ & Naik
\end{tabular}

Sumber : Diolah Penelitian,2021

Berdasarkan tabel diatas dari perhitungan bahwa kontribusi pembayaran Pajak Kendaraan Bermotor terhadap pendapatan asli daerah provinsi jawa timur dari tahun 2018 hingga tahun 2020 sangat bermacam - macam dan dari tahun ke tahunnya mengalami kenaikan /atau penigkatan. Dari tahun ke tahun tingkat kontribusi dari presentasinya mengalami kenaikan, yang dimana pada tahun 2020 tingkat kontribusi 


\section{Jurnal Sustainable}

Vol. 01, No. 1, Mei, 2021

http://journal.um-surabaya.ac.id/index.php/sustainable/index

presentasinya yang lebih tinggi dari tahun sebelumnya, hal ini terjadi adanya bahwa target yang ditetapkan pada tahun 2020 tersebut itu diturunkan. Sehingga Target tahun 2020 berbeda dari tahun 2018 hingga tahun 2019 bahwa target yang tetapkan makin dinaikkan akantetapi diikuti dengan realisasi yang naik pula, dibandingkan tahun 2020 realisasi dalam penerimaannya menurun dari pada tahun 2018 hingga tahun 2019 akan. Pada awal bulan Maret tahun 2020 adanya pengumuman mengenai pertama kalinya pemerintah ada dua kasus pasien yang posiftif Covid-19 di Indonesia (sumber: kompas.com). Kemungkinan dibulan Januari dan Februari masyarakat gencar melakukan pembayaran wajib pajak karena pada saat itu perekonomian masyarakat mengalami kestabilan, tapi beranjak di bulan April pengumuman yang disampaikan oleh Gubernur Jawa Timur Khofifah Indar Parawansa adanya Pembatasan Sosial Berskala Besar (PSBB) dengan protokol kesehatan dan physical distancing yang tetap dijalankan (sumber: liputan6.com). sehingga tahun 2020 pendapatan yang diterima ini turun, meskipun ada kenainkan tapi tidak signifikan persentasenya tidak seperti di tahun 2018 hingga 2019, karena ditahun 2020tersebut masih ada bulan - bulan yang belum terdampak masa pandemi covid-19, apalagi pada tahun 2018 hingga tahun 2019 sebelum adanya masa pandemi covid- 19 targetyang ditetapkan itu meningkat dengan realisasi yg meningkat juga. Baru pada saat tahun 2020 target yang sudah ditetapkan itu diturunkan karena tahun tersebut terdampak pandemi covid-19.

Ditahun 2020 pemerintah telah memberikan kebijakan dengan pembebaskan denda keterlambatan pembayaran pajak kendaraan bermotor dan memberikan diskon kepada pemilik kendaraan pribadi dan badan usaha. Bahwa Keadaan ini diharapkan upaya kinerja dalam memaksimalkan pembayaran wajib pajak kendaraan bermotor di Badan Pendapatan Daerah Provinsi Jawa Timur sudah baik. Dan hal ini dibuktikan dari target telah ditetapkan pada tahun 2018 hingga 2020 dapat terealisasi dan dapat melebihi target yang sudah ditentukan. 


\section{Jurnal Sustainable}

Vol. 01, No. 1, Mei, 2021

http://journal.um-surabaya.ac.id/index.php/sustainable/index

b. Kontribusi realisasi Bea Balik Kendaraan Bermotor terhadap Pendapatan Asli Daerah

Tabel 10 Kontribusi Realisasi Bea Balik Nama Kendaraan Bermotor terhadap PAD Provinsi Jawa Timur Tahun 2018 - 2020

Tahun Realisasi BBNKB(Rp) Realisasi PAD(Rp) Kontribusi Keterangan

$(\%)$

\begin{tabular}{lllll}
\hline 2018 & 4.089 .296 .812 .767 & 15.104 .158 .339 .337 & $27,101 \%$ & Naik \\
\hline 2019 & 4.232 .540 .305 .900 & 15.553 .541 .429 .948 & $27,223 \%$ & Naik \\
\hline 2020 & 3.022 .188 .308 .400 & 14.438 .094 .667 .108 & $20,932 \%$ & Turun
\end{tabular}

Sumber: Diolah Penelitian,2021

Berdasarkan tabel diatas menunjukkan bahwapresentasi dari tahun 2018 hingga tahun 2019 mengalami kenaikan dan persentasi pada tahun 2020 mengalami penurunan, Meskipun pada tahun 2020 persentasenya menurun akan tetapi realisasinya dapat mencapai target yang sudah ditetapkan dan ini mengindikasikan bahwa pada masa pandemi covid-19 ini berdampak negatif dalam pembayaran wajib pajak mengenai bea balik nama kendaraan bermotor dapat dilihat dari persentasenya yang menurun,menurut Rizal dan Hidayah (2018) menyatakan bahwa bea balik nama kendaraan bermotor sangat minim karena banyaknya kendaraan bermotor yang tidak membayar pajak dengan berbagai alasan dan masih banyak menggunakan kendaraan non-BL.

Upaya yang telah pemerintah lakukan dalam meningkatkan penerimaan pajak kendaraan bermotor dan bea balik nama kendaraan bermotor dari tahun ke tahun selalu terlihat dimana - mana atau di media sosial yang diingatkan bahwa wajib pajak masih memiliki tanggung jawab dalam membayar pajak. Apalagi pada tahun 2020 dimana tahun ini merupakan terdampak adanya pandemi Covid-19. Oleh karena itu kebijakan yang diberikan oleh pemerintah selama pandemi Covid-19yaitu membebaskan denda keterlambatan untuk pajak kendaraan bermotor serta membebaskan sanksi administratif pajak kendaraan bermotor dan bea balik nama kendaraan bermotor, serta insentif diskon pokok pajak Kendaraan Bermotor bagi roda dua sebesar 15\% dan roda 


\section{Jurnal Sustainable}

Vol. 01, No. 1, Mei, 2021

http://journal.um-surabaya.ac.id/index.php/sustainable/index

empat atau lebih sebesar 5\% bagi wajib pajak yangtertuang dalam keputusan Gubernur Jatim Nomor 188/334/KPTS/013/2020. (sumber: dispendajatim.go.id).

\section{KESIMPULAN}

1. Kontribusi Pajak Kendaraan Bermotor dan Bea Balik Nama Kendaraan Bermotor dari tahun 2018 hingga 2020 PKB dapat dikatakan berkontribusi baik, sedangkan BBNKB dapat dikatakan berkontribusi sedang terhadap Pendapatan Asli Daerah. Pada tahun 2018 hingga tahun 2019 merupakan sebelum adanya masa pandemi Covid-19, sedangkan ditahun 2020 merupakan pada masapandemi Covid-19.

2. Beberapa komponen Pajak Daerah yaitu Pajak Kendaraan Bermotor dan Bea Balik Nama Kendaraan Bermotor merupakan pajakyang penerimaannya/pendapatan dapat diandalkan bagi penerimaan daerah, khususnya di Provinsi Jawa Timur. Kedua pajak tersebut diharapkan mampu meningkatkan penerimaan Pendapatan Asli Daerah yang dimanfaatkan dalam pembangunan di Provinsi Jawa Timur, sehingga kebutuhan masyarakat dapat terpenuhi pada masa pandemi Covid-19.

\section{SARAN}

1. Bagi Badan Pendapatan Daerah Provinsi Jawa Timur adalah sebisa mungkin dapat mempertahankan kebijakan yang telah diberikan pada masa pandemi Covid-19 serta lebih diupayakan kembali dengan memberikan keringan atau diskon pada pajak PKB dan BBNKB sehingga hal ini dapat meningkatkan kontribusi pajak daerahnya terhadap wajib pajak itu sendiri.

2. Bagi masyarakat Jawa Timur dengan adanya kebijakan pada masapandemi Covid-19 ini diharapkan dapat bekontribusi yang baik dan dapat berkerja sama dengan pemerintah daerah. Hal ini agar masyarakat dapat meningkatkan dalam kewajiban atau kesadarannya akan pentingnya membayar pajak yang dapat digunakan dalam meningkatkan pembangunannya untuk fasilitas masyarakat sendiri.

3. Bagi peneliti selanjutnya dapat melakukan tindak lanjut penelitian khususnya menambah variabel yang dapat mempengaruhi Pendapatan Asli Daerah di Provinsi Jawa Timur. Seperti Pajak Bahan Bakar Kendaraan Bermotor dan pajak daerah lainnya. 
Vol. 01, No. 1, Mei, 2021

http://journal.um-surabaya.ac.id/index.php/sustainable/index

\section{DAFTAR PUSTAKA}

Aswati, W. O., Mas'ud,A., Nudi,T.N. (Februari 2018). Pengaruh Kesadaran Wajib Pajak, Pengetahuan Pajak, dan Akuntanbilitas Pelayanan Publik terhadap Kepatuhan Wajib Pajak Kendaraan Bermotor. Jurnal Akuntansi dan Keuangan, Vol. 3 No. 1, h.29.

Walker, Aryani, Y. (2020). Efektivitas Pembayaran Wajib Pajak Kendaraan Bermotor dalam Meningkatkan Pendapatan Asli Daerah Provinsi Jawa Timur. Universitas Muhammadiyah Surabaya.

Badan Pendapatan Daerah Provinsi Jawa Timur. (Juli 2020). Gubernur Khofifah Perpanjang Diskon Pajak Kendaraan Bermotor Hingga 31 Agustus. Surabaya: Kementrian Keuangan.

https://www.dipendajatimgo.id

DPRD Provinsi Jawa Timur. (2021). Dewan Lewat Komisi A hingga E berikan Masukan Terhadap PAPBD 2020. Surabaya: Dewan Perwakilan Rakyat Daerah Provinsi Jawa Timur. http://www.dprd.jatimprov.go.id

Erithrina, Y. Rengkung, L. R. Ngangi, C. R. (Januari 2018). Efektivitas Pemungutan Pajak Kendaraan Bermotor dan Bea Balik Nama Kendaraan Bermoto di BP2RD Provinsi Sulawesi Utara. Jurnal Transdisiplin Pertanian, Sosial dan Ekonomi, Vol. 14 No.1.

Fatihudin, D. (Februari 2020). Metodologi Penelitian untuk Ilmu Ekonomi, Manajemen dan Akuntansi, Sidoarjo: Zifatma.

Fikrianto, R. A. (2018). Implementasi Bela Negara Dalam Praktik Akuntansi. Universitas Pembangunan Nasional "Veteran" Jawa Timur.

Fitri, N. A. (2020). Efektifitas dan Kontribusi Pajak Air Permukaan terhadap Pendapatan Asli Daerah Di Provinsi Jawa Timur. Universitas Airlangga.

Halim, A., Bawono, I., Dara, A. (2020). Perpajakan: Konsep, Aplikasi, Contoh, dan Studi Kasus. Jakarta: Salemba Empat.

Ikatan Akuntansi Indonesia. (2021). IAI peduli Covid-19: Percepatan Penanganan Covid-19 dari perspektif Akuntan Kontribusi Pemikiran Akuntan Indonesia Refleksi 63 Tahun IAI (1957- 2020). Jakarta Pusat: Ikatan Akuntansi Indonesia. http://www.iaiglobal.or.id

Islam, D. (2020). Analisis Kontribusi Pajak Kendaraan Bermotor dan Bea Balik Nama Kendaraan Bermotor Terhadap Pendapatan Asli Daerah (PAD) Provinsi Jawa Timur Tahun 2013 - 2017. Universitas Islam Negeri Sunan Ampel 


\section{Jurnal Sustainable}

Vol. 01, No. 1, Mei, 2021

http://journal.um-surabaya.ac.id/index.php/sustainable/index

Kementrian Keuangan Republik Indonesia. (2020). Penerimaan Pajak Capi Rp 1.019,56 Trilliun atau 85,65\% dari target. Jakarta: Kementrian Keuangan. https://www.kemenkeu.go.id

Kompas. (Mei 2020). Diumumkan Awal Maret, Ahli: Virus Corona Masuk Indonesia dari Januari. http://www.kompas.com

Liputan 6. (April 2020). PSBB di Jawa Timur 28 April 2020, dari Sosialisasi hingga Sanksi Pelanggar. http://www.liputan6.com

Mariyani. Alfansyur, A. (Desember 2020). Seni Mengelola Data: Penerapan Triangulasi Teknik, Sumber dan Waktu pada Penelitian Pendidikan Sosial. Jurnal Kajian, Penelitian dan Pengembangan Pendidikan Sejarah. Vol. 5 No.2, h. 148.

Novianti, D.,Saputri, R, Sari, I., Parasian, W., $\quad$ Trihartanto, $\quad$ A., $\quad$ Imaluddin, A. (Januari 2020). Covid-19: Catatan Linimasa Para Analisis Muda. Jakarta: PT Gramedia.

Peraturan Pajak. (November 2021). Undang - $\quad$ undang Republik Indonesia Nomor 28 Tahun 2009. Jakarta Utara: Peraturan Pajak. http://www.peraturanpajak.com

Putri, A. (2017). Kontribusi Pajak Kendaraan Bermotor dan Pajak Bea Balik Nama Kendaraan Bermotor terhadap Pendapatan Asli Daerah Provinsi Jawa Timur. Universitas Brawijaya.

Purnawati, E. (Januari 2021). Konstribusi Pajak Kendaraan Bermotor dan Pajak Bea Balik Nama Kendaraan Bermotor pada Pendapatan Asli Daerah. Jurnal Ekonomi dan Bisnis, Vol. 19 No.1, h. 20.

Rakatitha, P. N. K. (November 2017). Pengaruh Kontribusi Pajak Kendaraan Bea Balik Nama Kendaraan Bermotor pada Pendapatan Asli Daerah. Jurnal Akuntansi Universitas Udayana, Vol. 21 No.2.

Resmi, S. (Januari 2019). Perpajakan: Teori dan Kasus. Jakarta: Salemba Empat.

Rizal, Y., Hidayah, M. (Januari 2018). Analisis Kontribusi Pajak Kendaraan Bermotor (PKB) dan Bea Balik Nama Kendaraan Bermotor (BBNKB) di SAMSAT Aceh Timur terhadap Pendapatan Asli Daerah (PAD) Provinsi Aceh. Jurnal Samudra Ekonomi dan Bisnis, Vol 9 No. 1.

Saputra, E., Putri, N. E. ( November 2020). Perngaruh PKB, BBNKB, Dan PBBKB terhadap PAD. Junrnal IKRA-ITH Ekonomika, Vol. 3 No 3, h. 136. 